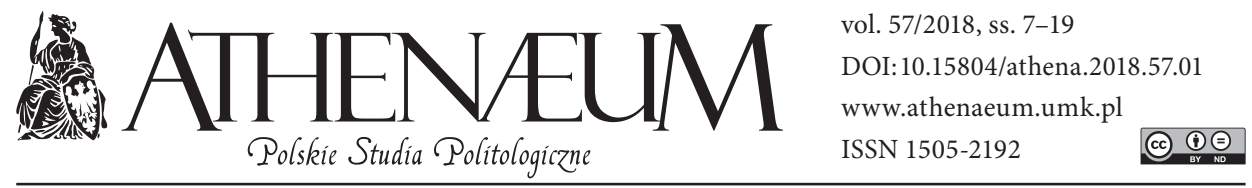

\title{
KOŚCIÓł KATOLICKI W POLSCE JAKO PODMIOT ODDZIAŁUJACCY NA SYSTEM POLITYCZNY. CASUS REGULACJI PRAWNYCH O ZAPŁODNIENIU POZAUSTROJOWYM IN VITRO
}

\author{
THE CATHOLIC CHURCH IN POLAND AS A SUBJECT \\ AFFECTING THE POLITICAL SYSTEM: \\ CASUS OF LEGAL REGULATIONS OF EXTRACORPOREAL \\ FERTILIZATION IN VITRO
}

Krzysztof Kowalczyk*

\begin{abstract}
ABSTRAKT
Celem artykułu jest określenie oddziaływania Kościoła katolickiego na system polityczny w Polsce odwołanie się do case study - form sprzeciwu Kościoła wobec legalizacji metody zapłodnienia pozaustrojowego in vitro. W nauce o polityce Kościól jest określany jako organizacja wyznaniowa, grupa interesu, aktor polityczny. Autor definiuje Kościół (jako) podmiot, który oddziałuje na system polityczny i jego otoczenie w formie bezpośredniej, pośredniej i sankcji moralnych. Biskupi katoliccy sprzeciwiali się regulacji in vitro, ingerując między innymi w przebieg procesu legislacyjnego. Świadczy to o doniosłym wpływie Kościoła w Polsce na sferę publiczną.
\end{abstract}

Słowa kluczowe: Kościół katolicki, Polska, system polityczny, in vitro
The aim of this article is to determine the influence of the Catholic Church on the political system in Poland, by referring to the case study - forms of opposition of the Church to legalize the method of in vitro fertilization. In science of politics the church is referred to as a religious organization, interest group, a political actor. The author defines the Church entity which affects the political system and its environment in the form of direct, indirect and moral sanctions. Catholic bishops opposed the regulation of in vitro by interfering, among others, in the legislative process. This demonstrates the major influence of the Church in Poland in the public sphere.

Keywords: Catholic Church, Poland, political system, in vitro

\footnotetext{
* Uniwersytet Szczeciński, Instytut Politologii i Europeistyki.
} 
Problematyka dotycząca wpływu Kościoła katolickiego na instytucje polityczne i społeczeństwo nie znajduje się w głównym nurcie rozważań politologów. Zdefiniowanie roli Kościoła w nauce o polityce napotyka na liczne trudności i rozbieżności interpretacyjne. Przesłanki tego stanu rzeczy są trojakie. Po pierwsze, pewna grupa badaczy, określając rolę Kościoła w systemie politycznym, reprezentuje stanowisko normatywne, dając wyraz swoim poglądom i preferencjom politycznym (zob. Góra-Szopiński, 2015). Po drugie, Kościół postrzegany jest przez politologów często nie jako kluczowy, a peryferyjny podmiot w otoczeniu systemu politycznego. Po trzecie, w myśl posoborowego nauczania społecznego Kościoła, jego centralnym zadaniem jest ewangelizacja, a w sferze publicznej powinien on funkcjonować przede wszystkim w wymiarze metapolitycznym, a nie bieżącej polityki.

Zasadniczym celem artykułu jest określenie oddziaływania Kościoła katolickiego na system polityczny w Polsce poprzez odwołanie się do case study - form sprzeciwu Kościoła wobec legalizacji metody zapłodnienia pozaustrojowego in vitro. W celu realizacji powyższego zamierzenia badawczego określono najpierw, jakie są kierunki definiowania Kościoła w nauce o polityce. Następnie zaproponowano typologię form oddziaływania Kościoła na system polityczny. Potem syntetycznie scharakteryzowano historię legalizacji in vitro oraz zanalizowano argumentację i formy oddziaływania Kościoła w procesie stanowienia powyższych regulacji. Przez pojęcie Kościół należy rozumieć „Kościół hierarchiczny”, nie zaś wspólnotę wiernych. Termin ten jest tożsamy z katolicką hierarchią kościelną, tj. biskupami, w szczególności diecezjalnymi. Biskupi współkształtują Nauczanie Społeczne Kościoła (NSK) poprzez: wydawanie listów pasterskich, głoszenie homilii, udzielanie wywiadów. Na terytorium Polski biskupi skupiają się w ramach Konferencji Episkopatu Polski (KEP). Organ ten wydaje dokumenty będące rozwinięciem NSK w formie: listów pasterskich, komunikatów, oświadczeń oraz podejmuje dialog z władzami politycznymi. Dla rozwiązania kluczowego problemu badawczego zastosowano metodę analizy systemowej (Kościół w systemie politycznym), wzbogaconą o studium przypadku (spór o regulacje prawne in vitro). Kwestię wpływu Kościoła katolickiego w Polsce na system polityczny podejmowali przede wszystkim: Marek Delong, Jarosław Gowin, Anja Hennig, Dominik Hierlemann, Krzysztof Kowalczyk, Henryk Skorowski, Sławomir Sowiński (Delong, 2016; Gowin, 1999; Hennig, 2012; Hierlemann, 2005; Kowalczyk, 2016; Skorowski, 2009; Sowiński, 2012).

Kościół jest definiowany w różnorodny sposób przez reprezentantów nauk o polityce jako: wspólnota - organizacja religijna, grupa interesów, aktor polityczny i religijny. 
Kościół jako organizację religijną określają m.in. Heindrun Abromeit i Wolfgang Ernst Bökenförde (Abromeit, 1989; Bökenförde, 1994). W kontekście obecności Kościoła w przestrzeni społeczno-politycznej civil society W.-E. Böckenförde określa go dwojako. Po pierwsze, jako wspólnotę religijną tworzącą organizacyjno-instytucjonalną jedność, reprezentowaną przez zwierzchników piastujących urzędy i jednolicie działających. Po drugie, jako zbiorowość wiernych, którzy zamierzają żyć według wskazań religii i realizować jej zasady w życiu bez występowania jako jednolity, instytucjonalny podmiot. Dla niniejszej pracy istotne znaczenie ma pierwszy sposób definiowania Kościoła. W.-E. Böckenförde zwraca uwagę, że celem Kościoła instytucjonalnego jest realizowanie misji, która ma charakter duchowo-religijny, nie zaś polityczny: „Jej celem nie jest ani zachowanie, ani likwidacja politycznych porządków i systemów, ani też uczestnictwo w rozgrywkach partyjnych" (Böckenförde, 1994). Głosząc swoje przesłanie, wspólnota religijna oddziałuje na życie ludzi i porządek życia zbiorowego. Innymi słowy, misja Kościoła instytucjonalnego jest w nieunikniony sposób działaniem politycznym. Kościół znajduje się w obszarze działań politycznych, chociaż nie jest to główne pole jego funkcjonowania (Böckenförde, 1994).

W kategoriach grupy interesu Kościół jest definiowany m.in. przez Carolyn M. Warner i D. Hierlemanna. Przyjmujemy, że grupy interesu to formalne organizacje, które dążą do wywierania wpływu na demokratyczny proces polityczny (Zeiger, 1992). Określając Kościół katolicki jako nietypową grupę interesów (atypical interest group), C.M. Warner konstatuje, że taki Kościół dąży do preferencyjnego traktowania go przez władzę polityczną, a jego celem jest uzyskanie określonych zasobów z systemu ekonomicznego i politycznego. Kościół lobbuje demokratyczne rządy za pośrednictwem partii politycznych i innych środków, aby mieć m.in. wpływ na system edukacji, narzucić swoją moralność społeczeństwu przez ustawodawstwo, czy zachować niektóre przywileje podatkowe. Swoim członkom stara się zapewnić pewne dobra zbiorowe (jak odpowiedzi na dylematy moralne i filozoficzne), stowarzyszeniowe (np. miejsce kultu) czy zachęty indywidualne (np. sakramenty). Kościół katolicki oprócz tego, że jest zorganizowaną religią, można określić jako grupę interesów. Jest to jednak grupa nietypowa. Po pierwsze, Kościół odwołuje się do swojego autorytetu moralnego, twierdzi, że jego zasady są powszechnie stosowane. Po drugie, jest instytucją ponadnarodową, wszystkie krajowe „filie” mają „złożyć hołd” Watykanowi. Jednocześnie Kościoły krajowe, posiadające własną historię, struktury, liderów i polityczne interesy, mogą różnić się w akcentach doktrynalnych i duszpasterskich. Po trzecie, stara się zachować kontrolę nad takimi aspektami życia czło- 
wieka, jak wartości, moralność, sumienie, które większość grup interesu uznaje za sferę indywidualną (Warner, 2000). Według C.M. Warner Kościół jest zatem grupą interesów, która sprzedaje swój produkt na rynku religijnym (obrządek i zbawienie). Kościół nie znosi konkurencji w postaci innych religii i ideologii. W systemie demokratycznym ta grupa interesów będzie dążyła do utrzymania swojej monopolistycznej pozycji poprzez państwo i partie (szczególnym sprzymierzeńcem Kościoła katolickiego jest chrześcijańska demokracja; Warner, 2000). Dla poparcia swoich interesów stosuje techniki lobbingowe zaadaptowane do realiów demokracji (Warner, 2000).

Podobnie D. Hierlemann stwierdza, że Kościół działa jako reprezentant interesów i lobbysta, który próbuje nawiązać ważne kontakty, ustanowić dobre relacje z decydentami i grać o zasoby. Kościól, działając w sferze świeckiej, podlega tym samym zasadom, jak inne stowarzyszenia (Verbände). Instytucja ta stara się realizować swoje interesy w procesie politycznym. W oparciu o teorie funkcjonowania stowarzyszeń w obszarze świecko-politycznym można badać zatem działalność Kościoła w systemie politycznym (Hierlemann, 2005). Z tej perspektywy D. Hierlemann analizuje różne formy lobbingu Kościoła katolickiego w Polsce (Hierlemann, 2005).

Thomas Poguntke rozpatruje kościoły w kategoriach political actors, zatem wpływowych podmiotów politycznych/aktorów politycznych nie tylko ze względu na prosty fakt, że ich związki z systemem politycznym są wysoce zinstytucjonalizowane $\mathrm{w}$ wielu krajach (Poguntke, 2012). Podobnie w kategoriach nietypowego aktora sceny politycznej w Polsce Kościół katolicki określa W. Wesołowski. W jego przekonaniu szczególna rola Kościoła wynika z zakorzenienia w tradycji narodowej i stworzenia ochrony dla wolności w okresie komunistycznym (Wesołowski, 2000). W warunkach słabości partii politycznych po 1989 r., w tym braku zjednoczonej partii chrześcijańsko-demokratycznej, hierarchia kościelna stawała się „uczestnikiem procesu politycznego w sprawach interesujących katolików" (Wesołowski, 2000). Kwestie dotyczące treści konstytucji były wprawdzie artykułowane przez małe partie w procesie politycznym, przede wszystkim jednak stanowiły przedmiot negocjacji między parlamentem, rządem i episkopatem. Jak stwierdza W. Wesołowski: „W ten sposób instytucja niepolityczna uczestniczy w życiu politycznym" (Wesołowski, 2000).

Natomiast Anja Hennig, Jose Casanova, Michael Minkenberg rozpatrują Kościół katolicki w kategoriach tradycyjnego aktora religijnego (traditional religious actors), funkcjonującego w sferze publicznej (Hennig, 2011). Za nowatorską próbę zdefiniowana roli Kościoła katolickiego w Polsce w sferze polityki należy 
uznać propozycję Krzysztofa Zuby. Pisze on o trzech politycznych obliczach tej instytucji: protektora politycznego, kreatora wartości, grupy interesu (Zuba, 2012).

W niniejszym artykule w ujęciu stricte politologicznym Kościół jest definiowany jako podmiot znajdujący się w otoczeniu systemu politycznego i oddziałujący na ten system. Podmiotowość w tym kontekście oznacza możliwość realizowania swoich celów, zamierzeń i działań, w tym sensie Kościół jest zinstytucjonalizowanym podmiotem sprawczym. Jest bowiem strukturą zorganizowaną, zhierarchizowaną. Członkowie podmiotu sprawczego przekazują część swoich atrybutów na poziom ugrupowania, w skład którego wchodzą. Ta zależność - delegacja uprawnień - wyraża się lojalnością i podporządkowaniem decyzjom podejmowanym na poziomie owego ugrupowania (Wnuk-Lipiński, 2005). Na poziomie Kościoła powszechnego kluczowe decyzje podejmowane są przez papieża, w zespole Kościołów krajowych (czyli zespole Kościołów partykularnych w danym państwie) przez episkopat i jego prezydium, w Kościele partykularnym przez biskupa - rządcę diecezji. Pojęcie systemu politycznego jest określane jako ogół instytucji politycznych, za pośrednictwem których podejmowane są decyzje polityczne, oraz generalnych norm i zasad regulujących stosunki między nimi. W ujęciu instytucjonalnym pojęcie instytucji politycznych odnosi się do zorganizowanych aktorów politycznych, przede wszystkim organów państwowych, partii politycznych. W ujęciu neoinstytucjonalnym instytucje polityczne są określane jako reguły gry i struktury, ucieleśniające pewne wartości i układ sił oraz determinujące odpowiednie zachowania jednostek w określonych kontekstach (March, Olsen, 1989). W celu urzeczywistnienia wartości i artykulacji interesów Kościół wywiera zatem wpływ na partie polityczne, aby oddziaływały na proces legislacyjny i rządowy proces decyzyjny, oraz bezpośrednio na poszczególne organy władzy - parlament, rząd, sądy i trybunały. Kościół wywiera również wpływ na formalne i nieformalne reguły funkcjonowania systemu politycznego, a tym samym na zachowania zbiorowych i indywidualnych aktorów politycznych. Z perspektywy neoinstytucjonalizmu normatywnego można zatem przeprowadzić analizę oddziaływania Kościoła na system polityczny w ujęciu dynamicznym.

Strategie czy też formy oddziaływania Kościoła na instytucje polityczne były przedmiotem badań Zsolta Eneydi, a w szczególności D. Hierlemanna. Analizując wpływ kościołów na proces polityczny, Z. Enyedi wymienił następujące strategie: lobbing, budowanie koalicji z innymi kościołami i aktorami politycznymi, wywieranie presji poprzez mobilizowanie opinii publicznej dla swoich 
celów (Enyedi, 2003). Odnosząc się do oddziaływania Kościoła katolickiego na system polityczny w Polsce, D. Hierlemann wyodrębnił: 1) ścieżki wpływu Kościoła; 2) lobbing Kościoła. W pierwszym przypadku Kościół wpływał na trzy podmioty: a) partie polityczne; b) parlament; c) rząd i Komisję Wspólną Rządu i Episkopatu (KWRiE). Kontakty nieformalne, personalne biskupów z politykami poszczególnych partii były preferowane bardziej niż formalny dialog. Jako lobbysta Kościół korzystał z doświadczeń historycznych (w tym rozmów z władzami PRL) i orientował w konkretnej sytuacji. Działał spontanicznie, wykorzystując kontakty z mediami, urzędnikami i politykami zarówno w wymiarze personalnym, jak i poprzez zinstytucjonalizowane struktury kontaktu (poprzez KWRiE czy parlamentarne komisje sejmowe). Hierlemann zwrócił uwagę na istnienie w parlamencie tzw. wewnętrznego lobby (interne lobby) Kościoła. Lobby to stanowili deputowani związani z Kościołem poprzez przynależność osobową do niego (przynależność relacyjna), socjalizację, wiarę, kontakty z dostojnikami kościelnymi (przynależność afektywna). Starali się zabezpieczyć jego pozycję w polityce i społeczeństwie poprzez regulacje prawne (przynależność tematyczna; Hierlemann, 2005).

Wymienione propozycje mogą stanowić punkt wyjścia do skonstruowania własnej typologii oddziaływania Kościoła krajowego na system polityczny. Przedstawiona poniżej propozycja typologii uwzględnia specyfikę funkcjonowania Kościoła katolickiego w Polsce. Rozpatrując oddziaływanie Kościoła krajowego na system polityczny, należy wyróżnić kryterium podmiotowe, przedmiotowe, formy oddziaływania i zamierzonego celu.

Podmiotem oddziaływania Kościoła krajowego są organy władzy państwowej oraz partie, grupy interesów, media i społeczeństwo. Kryterium przedmiotowe pozwala na wyodrębnienie następujących kwestii problemowych, podejmowanych przez Kościoły krajowe: sfera bieżącej polityki (stanowiska wobec wyborów, referendów); preferowany model stosunków wyznaniowych (zawarty w przepisach konstytucyjnych, konkordatu, ustawach i rozporządzeniach); kwestie społeczno-ekonomiczne (dezyderaty, dotyczące polityki społecznej, w tym rodzinnej); finansowe i majątkowe aspekty działalności Kościoła (subwencjonowanie Kościoła ze środków państwowych, podatek kościelny, kwestie własności kościelnej); funkcjonowanie w Unii Europejskiej (respektowanie wartości chrześcijańskich w ustawodawstwie unijnym).

Formy oddziaływania Kościoła na system polityczny i podmioty znajdujące się w jego otoczeniu są często zbliżone do metod i technik właściwych dla lobbingu. Celem tego oddziaływania jest artykulacja własnych wartości i inte- 
resów oraz przekonanie decydentów politycznych do określonych rozwiązań prawnych i administracyjnych. Można wyróżnić dwie formy oddziaływania Kościoła z uwagi na kryterium sposobu artykulacji wartości i interesów: 1) bezpośrednie i 2 ) pośrednie. W pierwszym przypadku biskupi bezpośrednio oddziałują na decydentów, w drugim zaś korzystają z pośrednictwa innych podmiotów. W ramach oddziaływania bezpośredniego można wyróżnić formy ustne i pisemne. Do formy ustnej należą: oficjalne i zakulisowe rozmowy, spotkania, konferencje, sympozja z politykami. Natomiast do formy pisanej można zaliczyć: listy, oświadczenia, dezyderaty, opracowania kierowane do decydentów politycznych. Kościół instytucjonalny dąży do realizacji swoich celów i interesów za pośrednictwem następujących podmiotów: grup interesów (stowarzyszeń, fundacji, związków zawodowych, grup niesformalizowanych), wspólnych organów kościelno-państwowych, mass mediów, ekspertów, naukowców, mobilizacji opinii publicznej. Szczególną formą oddziaływania Kościoła instytucjonalnego na system polityczny, wykraczającą poza klasyczne metody lobbingu, są sankcje moralne. Mobilizują i skłaniają one indywidualnych i zbiorowych aktorów politycznych do działań zgodnych z wartościami i interesami Kościoła. Sankcje moralne są reakcjami Kościoła na zachowania swoich członków w sytuacjach społecznie ważnych. Sankcje moralne mogą mieć charakter pozytywny - wzmacniający, są to: pochwały, wyrazy publicznego uznania czy wsparcia dla określonego aktora politycznego, np. opowiadającego się za opcją pro-life w parlamencie. Repertuar sankcji negatywnych jest zróżnicowany: od negatywnej oceny poczynań polityka, jego potępienia, poprzez zerwanie z nim kontaktów, po groźbę ekskomuniki.

Z uwagi na zamierzone cele można przyjąć podział form wpływu Kościoła na strategie ofensywne i defensywne. Strategie ofensywne mają na celu rozszerzenie zakresu obowiązującego ustawodawstwa w sposób zgodny z wartościami i interesami Kościoła (np. poszerzenie zakresu obwiązywania ustawy antyaborcyjnej). Strategie defensywne zmierzają do utrzymania status quo (np. działania przeciw liberalizacji ustawy antyaborcyjnej).

Jednym z przykładów oddziaływania Kościoła w Polsce na system polityczny jest kwestia sprzeciwu tej instytucji wobec regulacji prawnych sankcjonujących in vitro. Metoda zapłodnienia pozaustrojowego in vitro należy do kategorii nowych „technologii reprodukcyjnych”, czyli sztucznej prokreacji. Stwarza ona możliwości rodzicielstwa bezpłodnym kobietom i parom. W parlamencie po raz pierwszy w 2004 r. posłowie Sojuszu Lewicy Demokratycznej (SLD) w ramach projektu ustawy o świadomym macierzyństwie opowiedzieli się za 
Tabela 1. Typologia oddziaływania Kościoła krajowego na system polityczny i jego otoczenie

\begin{tabular}{|c|c|c|c|c|c|}
\hline \multicolumn{6}{|c|}{ Kryterium } \\
\hline \multirow{2}{*}{ Podmiotowe } & \multirow{2}{*}{ Przedmiotowe } & \multicolumn{3}{|c|}{ Formy oddziaływania } & \multirow{2}{*}{ Cele } \\
\hline & & Bezpośrednie & Pośrednie & Sankcje moralne & \\
\hline $\begin{array}{l}\text { 1. Instytucje } \\
\text { władzy } \\
\text { państwowej } \\
\text { (egzekutywa, } \\
\text { legislatywa, } \\
\text { sądy } \\
\text { i trybunały). } \\
\text { 2. Partie } \\
\text { polityczne } \\
\text { i ugrupowania. } \\
\text { 3. Grupy } \\
\text { interesów. } \\
\text { 4. Mass media. } \\
\text { 5. Społeczeń- } \\
\text { stwo. }\end{array}$ & $\begin{array}{l}\text { 1. Sfera bieżącej } \\
\text { polityki. } \\
\text { 2. Model } \\
\text { stosunków } \\
\text { wyznaniowych. } \\
\text { 3. Kwestie } \\
\text { społeczno-eko- } \\
\text { nomiczne. } \\
\text { 4. Finansowe } \\
\text { i majątkowe } \\
\text { aspekty } \\
\text { działalności } \\
\text { Kościoła. } \\
\text { 5. Funkcjo- } \\
\text { nowanie Unii } \\
\text { Europejskiej. }\end{array}$ & $\begin{array}{l}\text { 1. Ustne: } \\
\text { rozmowy, } \\
\text { spotkania } \\
\text { z politykami. } \\
\text { 2. Pisemne: } \\
\text { listy, } \\
\text { oświadczenia, } \\
\text { dezyderaty, } \\
\text { opracowania. }\end{array}$ & $\begin{array}{l}\text { 1. Oddziały- } \\
\text { wanie przez } \\
\text { podmioty: } \\
\text { grupy interesu, } \\
\text { agendy } \\
\text { państwowo- } \\
\text {-kościelne, } \\
\text { mass media, } \\
\text { eksperci, } \\
\text { naukowcy, } \\
\text { autorytety. } \\
\text { 2. Apele } \\
\text { do opinii } \\
\text { publicznej: } \\
\text { - manifestacje, } \\
\text { happeningi, } \\
\text { - akcje } \\
\text { obywatelskiego } \\
\text { nieposłuszeń- } \\
\text { stwa, } \\
\text { - petycje, listy, } \\
\text { e-mailing, } \\
\text { e-lobbing. }\end{array}$ & $\begin{array}{l}\text { 1. Pozytywne: } \\
\text { pochwały, poparcie } \\
\text { dla polityka. } \\
\text { 2. Negatywne: } \\
\text { publiczna krytyka } \\
\text { i dyskredytacja, } \\
\text { groźba } \\
\text { ekskomuniki, } \\
\text { ekskomunika. }\end{array}$ & $\begin{array}{l}\text { 1. Poszerze- } \\
\text { nie status } \\
\text { quo. } \\
\text { 2. Utrzyma- } \\
\text { nie status } \\
\text { quo. }\end{array}$ \\
\hline
\end{tabular}

Źródło: opracowanie własne.

refundacją zabiegów in vitro. W 2009 r. do Sejmu wpłynęło sześć projektów ustaw, od zakazujących in vitro (komitetu obywatelskiego „Contra in vitro”, dwu Prawa i Sprawiedliwości - PiS), poprzez rozwiązanie pośrednie - tworzenie maksymalnie dwu zarodków implantowanych do organizmu kobiety (autorstwa Jarosława Gowina z Platformy Obywatelskiej - PO), po regulacje dopuszczające metodę in vitro (propozycje Małgorzaty Kidawy-Błońskiej z PO i Marka Balickiego z SLD). W Sejmie VI kadencji kwestia in vitro nie została jednak uregulowana (Kowalczyk, 2016; Gozdecka, 2012). Po wyborach 2011 r. kluby parlamentarne przedstawiły nowe projekty ustaw. Projekty Ruchu Palikota, SLD 
i PO legalizowały procedurę in vitro. Dwa projekty PiS zmierzały do zakazania stosowania tej metody. Ostatecznie 25 czerwca 2015 r. Sejm przegłosował projekt PO (określany jako rządowy) - ustawę o leczeniu niepłodności. Zakłada ona, że z procedury in vitro mogą korzystać małżeństwa i osoby będące we wspólnym pożyciu, potwierdzonym zgodnym oświadczeniem obojga. Liczbę zapłodnionych komórek jajowych ograniczono do sześciu. Zakazano niszczenia zarodków, które nie są zdolne do prawidłowego rozwoju, pod sankcją kary - od 6 miesięcy do 5 lat pozbawienia wolności. Zabroniono również tworzenia zarodków w innych celach niż zapłodnienie pozaustrojowe (Ustawa...).

W trakcie prac nad ustawą minister zdrowia Bartosz Arłukowicz wprowadził od 1 lipca 2013 r. trzyletni program leczenia niepłodności, który objął 15 tys. par. Jednocześnie senatorowie PiS złożyli wniosek do Trybunału Konstytucyjnego (TK) w sprawie uznania niekonstytucyjności tego programu. W listopadzie 2015 r. minister zdrowia Maciej Zębala przedłużył program do końca $2016 \mathrm{r}$. Po wyborach parlamentarnych 2015 r. i utworzeniu rządu przez PiS, w grudniu 2016 r. minister zdrowia Konstanty Radziwiłł zapowiedział kontynuowanie tego programu tylko do pierwszej połowy $2016 \mathrm{r}$. W jego miejsce ministerstwo wprowadziło program kompleksowej oceny zdrowia prokreacyjnego, realizowany od 1 września 2016 r. do 31 grudnia 2020 r. Niezależnie od inicjatyw parlamentu i rządu od końca 2011 r. rady miast podejmowały uchwały w sprawie dofinansowania procedury in vitro.

Kościół był przeciwnikiem samej metody in vitro, pobierania zarodkowych komórek macierzystych z tzw. embrionów nadliczbowych, powstałych w wyniku zapłodnienia pozaustrojowego, legalizacji i finansowania tej metody przez państwo. W wymiarze etycznym zwracano uwagę, że życie człowieka, także embrionu, stanowi wartość nadrzędną. Zarodki ludzkie nie mogą być zatem likwidowane, zamrażane ani być przedmiotem handlu. W praktyce stosowana metoda in vitro jest selektywną aborcją czy eugeniką. Metoda in vitro uprzedmiotawia człowieka do roli narzędzia w procesach biotechnologii. Poczęcie dziecka w ten sposób jest naruszeniem godności człowieka, ponieważ następuje ono nie w wyniku aktu miłości, lecz w drodze eksperymentalnej procedury technicznej. Pod względem religijno-etycznym procedura in vitro jest przekroczeniem praw boskich i ludzkich. Poczęcie w ten sposób dziecka niesie dla kobiety istotne konsekwencje psychologiczne, staje się źródłem specyficznego syndromu. W wymiarze medycznym eksponowano kwestię skutków zdrowotnych dla dzieci poczętych metodą in vitro i ich matek. U dzieci poczętych tą metodą rośnie ilość wad wrodzonych. Istnieje również duże ryzyko chorób u kobiet poddawanych 
tym zabiegom. Częste przy in vitro ciąże mnogie kończą się przedwczesnym porodem. Stosowanie tej techniki może nieść za sobą nieprzewidywalne skutki biologiczne dla całej ludzkości. Wprowadzenie metody in vitro ma dla rodziny istotne konsekwencje społeczne. Dziecko poczęte w wyniku tej procedury może mieć trzy matki: genetyczną (dawczynię materiału genetycznego), biologiczną (tę, która je urodziła), społeczną (tę, która je wychowuje). Ustalenie ojcostwa jest jeszcze większym problemem, gdyż dawcy „materiału genetycznego” są najczęściej anonimowi, ale znane są wyjątkowe sytuacje, gdy pociąga się ich do obowiązku płacenia alimentów. W konsekwencji prawna legalizacja in vitro niesie za sobą redefinicję macierzyństwa, ojcostwa, wierności małżeńskiej, wprowadza chaos w relacjach rodzinnych i przyczynia się do podkopania fundamentów życia społecznego. Rodzinom, które nie mogły mieć potomstwa, proponowano skorzystanie z naprotechnologii lub adopcję dzieci. Zważywszy na przytoczone argumenty, biskupi oczekiwali od polityków, zwłaszcza parlamentarzystów głosowania przeciw legalizacji in vitro (Delong, 2016; Episkopat, 2015d; Kowalczyk, 2016).

W tym kontekście ustawa z 25 czerwca 2015 r. została negatywnie oceniona przez Kościół. Zwracano uwagę, że przyjęte regulacje traktują życie ludzkie w sposób przedmiotowy: „Legalizacja zapłodnienia in vitro jest zagrożeniem dla godności człowieka poczętego, narusza również godność ludzkiej prokreacji”. Krytycznie odnoszono się do dostępności in vitro dla par pozamałżeńskich, unicestwiania nadliczbowych zarodków (Episkopat, 2015a). Przewodniczący KEP abp Stanisław Gądecki w liście od prezydenta RP Bronisława Komorowskiego prosił go o przekazanie ustawy do ponownego rozpatrzenia Sejmowi lub skierowania do TK (Episkopat, 2015b). Podpisanie przez prezydenta RP ustawy arcybiskup uznał jako wyraz „skrajnego światopoglądu” (Episkopat, 2015c). Podobnie negatywnie biskupi oceniali narodowy program leczenia niepłodności.

W celu realizacji swojego postulatu - przeciwstawienia się legalizacji in vitro - Kościół zastosował różnorodne formy oddziaływania na system polityczny, zarówno pośrednie, jak i bezpośrednie. Do form bezpośrednich należy zaliczyć: listy pasterskie, komunikaty z zebrań plenarnych i dokument bioetyczny KEP; apele, oświadczenia, głosy Prezydium KEP; stanowisko Rady Stałej i Rady Naukowej KEP; oświadczenia, komunikaty Zespołu Episkopatu do spraw Bioetycznych; opinię Biura Prawnego i oświadczenie Rady Prawnej KEP; listy pasterskie biskupów; listy do polityków. Pośrednie formy oddziaływania były realizowane podczas posiedzeń KWRiE, za pośrednictwem grupy interesu, katolickich mass mediów, apeli naukowców. Podmiotem oddziaływania Kościoła 
byli w pierwszej kolejności decydenci polityczni: parlamentarzyści, członkowie rządu, prezydent RP, w drugiej - społeczeństwo. Przeciw usankcjonowaniu tej metody zapłodnienia pozaustrojowego występowali również przedstawiciele grup interesu związanych z Kościołem; oświadczenia, apele w tej sprawie wydały m.in. Polska Federacja Ruchów Obrony Życia, Krajowy Instytut Akcji Katolickiej. Kościół organizował sesje naukowe, debaty, wykłady, w mediach katolickich propagowano wypowiedzi naukowców - lekarzy, genetyków, lansując naprotechnologię. Negatywną ocenę projektu ustawy o leczeniu niepłodności przedstawiła, skupiająca katolickich prawników, Fundacja Instytut na Rzecz Kultury Prawnej Ordo Iuris. Jednocześnie począwszy od końca 2011 r. grupy interesu wspierały biskupów w działaniach przeciwko uchwaleniu przez rady miast programów dofinansowania in vitro. Biskupi deprecjonowali przy tym polityków optujących za regulacją prawną in vitro. W 2010 r. abp Henryk Hozer dopuszczał wręcz możliwość zastosowania ekskomuniki wobec posłów głosujących za legalizacją tej metody. W oświadczeniu z 4 sierpnia 2015 r. Rada Prawna KEP stwierdziła, że parlamentarzyści i prezydent RP, którzy poparli ustawę o leczeniu niepłodności, dopuścili się szczególnej formy zgorszenia, nie zaciągając jednak automatycznie ekskomuniki (Episkopat, 2015e).

Kościół katolicki w Polsce jest istotnym podmiotem oddziałującym na system polityczny i jego otoczenie. Stosuje przy tym różnorodne formy wpływu: bezpośrednie, pośrednie i sankcje moralne. Kwestie odnoszące się do implementacji norm i wartości katolickiej etyki życia rodzinnego w ustawodawstwo państwowe stanowią jeden z postulatów Kościoła. Różnorodne formy sprzeciwu biskupów i podmiotów ich wspierających wobec prób legalizacji zapłodnienia pozaustrojowego metodą in vitro stanowią egzemplifikację powyższego stwierdzenia. Przedstawiona przez autora typologia oddziaływania Kościoła na system polityczny i jego otoczenie może stanowić asumpt do konstruowania kolejnych klasyfikacji w tym zakresie.

\section{Bibliografia:}

Abromeit, H. (1989). Sind die Kirchen Interessenverbände?. W: H. Abromeit, G. Wewer (red.), Die Kirchen und die Politik. Beiträge zu einem ungeklärten Verhältnis (s. 244-260). Opladen: Westdeutcher Verlag.

Böckenförde, E.-W. (1994). Wolność - państwo - Kościół. Kraków: Znak.

Delong, M. (2016). Konferencja Episkopatu Polski wobec wybranych kwestii politycznych i społecznych $w$ Polsce w latach 1989-2914. Rzeszów: Uniwersytet Rzeszowski. 
Enyedi, Z. (2003). Conclusion: Emerging Issues in the Study of Church-State Relations. West European Politics 2003, vol. 26, issue 1, s. 218-232.

Gozdecka, D.A. (2012). The Polish Catholic Church and the Regulation of IVF in Poland: Polarised Political Discourses and the Battle over 'Proper' Reproduction. Feminist Law, vol. 2, no 1, s. 1-40.

Gowin, J. (1999). Kościół w czasach wolności 1989-1999. Kraków: ZNAK.

Góra-Szopiński, D. (2015). Czy może a czym nie powinna być politologia religii? W: R. Michalak (red.), Polityka jako wyraz lub następstwo religijności (s. 13-34). Sieniawa Żarska: Wydawnictwo Morpho.

Hennig, A. (2011). Conclusion. Pattern and Pespectives. W: J. Haynes, A. Hennig (red.), Religious Actors in the Public Sphere. Means, objectives and effects (s. 213-225). London: Routledge.

Hennig, A. (2012). Morapolitik und Religion. Bedigungen politisch-religiöser Kooperation in Polen, Italien und Spanien. Würzburg: Ergon-Verlag.

Hierlemann, D. (2005). Lobbying der katholischen Kirchen: Das Einflussentz des Klerus in Polen. Wiesbaden: VS Verlag für Sozialwissenschaften.

Kowalczyk, K. (2016). Między antyklerykalizmem a konfesjonalizacja. Partie polityczne wobec Kościoła katolickiego w Polsce. Toruń: Wydawnictwo MADO.

Episkopat. (2015a). Opinia Biura Prawnego KEP; „Dlaczego sprzeciw wobec uchwalonej przez Sejm w dniu 25 czerwca 2015 r. ustawie o leczeniu niepłodności, w sposób liberalny legalizujacej zapłodnienie in vitro". Pobrane z: http://episkopat.pl/dlaczego-sprzeciw-wobec-uchwalonej-przez-sejm-w-dniu-25-czerwca-2015-r-ustawyo-leczeniu-nieplodnosci-w-sposob-liberalny-legalizujacej-zaplodnienie-in-vitro/.

Episkopat. (2015b). List Przewodniczacego KEP do Prezydenta RP. Pobrane z: http:// episkopat.pl/list-przewodniczacego-kep-do-prezydenta-rp-2/.

Episkopat. (2015c). Odpowiedź Przewodniczącego Konferencji Episkopatu Polski na list Prezydenta RP z 22 lipca 2015 r. Pobrane z: http://episkopat.pl/odpowiedzprzewodniczacego-kep-na-list-prezydenta-rp-z-dnia-22-lipca-2015-r/.

Episkopat. (2015d). Kościół w Polsce o in vitro. Pobrane z: http://episkopat.pl/kosciol-w-polsce-o-in-vitro/.

Episkopat. (2015e). Oświadczenie w sprawie konsekwencji na płaszczyźnie sakramentalnej, wynikajacych z głosowania i podpisania ustawy dotyczacej procedury in vitro., Warszawa 3 sierpnia 2015 r. Pobrane z: http://episkopat.pl/oswiadczenie-w-sprawie-konsekwencji-na-plaszczyznie-sakramentalnej-wynikajacych-z-glosowaniai-podpisania-ustawy-dotyczacej-procedury-in-vitro/.

Poguntke, T. (2012). Series Editor's Preface. W: J. Haynes (red.), Religion and Politics in Europe, the Middle East and North Africa (s. XIV-XV). London: Routledge.

Skorowski, H. (2009). Kościół a polskie spory okresu transformacji. Warszawa: Wydawnictwo Naukowe UKSW.

Sowiński, S. (2012). Boskie, cesarskie, publiczne. Debata o legitymizacji Kościoła katolickiego $w$ sferze publicznej w Polsce w latach 1989-2010. Warszawa: Oficyna Wydawnicza ASPRA. 
Ustawa z dnia 25 czerwca 2015 r. o leczeniu niepłodności, Dziennik Ustaw 2015, poz. 1087.

Warner, C.M. (2000). Confessions of an Interest Group. The Catholic Church and Political Parties in Europe. New Jersey: Princeton University Press.

Wesołowski, W. (2000). Partie: nieustanne kłopoty. Warszawa: Wydawnictwo IPiS PAN.

Wnuk-Lipiński, E (2005). Socjologia życia publicznego. Warszawa: Wydawnictwo Naukowe Scholar.

Zeiger, H. (1992). Interest Groups. W: M. Hawkesworth, M. Kogan (red.), Ecyclopedia of Government and Politics, vol. I (s. 377-392). New York: Routledge.

Zuba, K. (2012). Polska scena polityczna. Ciagłość zmiana. Warszawa: Wydawnictwo Sejmowe. 